\title{
Evaluation of Web Accessibility of Higher Education Institutions in
} Chile

\author{
Carlos Máñez Carvajal ${ }^{1,2}$, Rocío Fernández Piqueras $^{2} \&$ Jose F. Cervera Mérida ${ }^{2}$ \\ ${ }^{1}$ Escuela de doctorado, Universidad Católica de Valencia San Vicente Mártir, Spain \\ ${ }^{2}$ Facultad de Psicología, Magisterio y Ciencias de la Educación, Universidad Católica de Valencia San Vicente \\ Mártir, Spain \\ Correspondence: Carlos Máñez Carvajal, Universidad Católica de Valencia San Vicente Mártir, Godella, Valencia, \\ Spain. Tel: 96-363-7412. E-mail: carlos.manez@ucv.es
}

Received: July 6, $2018 \quad$ Accepted: August 12, $2018 \quad$ Online Published: November 27, 2018

doi:10.5539/ies.v11n12p140 URL: https://doi.org/10.5539/ies.v11n12p140

\begin{abstract}
The aim of this study is to assess the web accessibility concerning the websites of Chilean universities which are listed in The World University Rankings.

Web accessibility is a fundamental factor in achieving a true educational inclusion. It is especially important in the light of the current trend of expanding not only the online content, but also online learning. What makes this even more essential is the Chilean legislation which under Law 20422 establishes the regulations regarding equality of opportunity and social inclusion of people with disabilities.

The analysis has been conducted on the basis of the international standard set by the World Wide Web Consortium (W3C), version WCAG 2.0. Evaluation methodology called WCAG-EM created by the same entity, has been applied in the analysis. Various automatic web accessibility evaluation tools have also been used, apart from manual verifications.

The study reveals that the websites of Chilean universities have hardly complied with the regulation and that there are barriers and difficulties of access for the elderly and/or people with disabilities.
\end{abstract}

Keywords: web accessibility, W3C, WCAG 2.0, disability, Chilean universities

\section{Introduction}

In the last years, higher education in Chile has shown extraordinary progress. Undoubtedly, Information and Communication Technologies (ICT) have revolutionized both teaching and learning, with the result that almost all institutions now offer virtual learning spaces.

The university has been evolving alongside the new technologies, benefiting immensely in the last years from the expansion of the Internet and the proliferation of last-generation technological devices, so much so that it seems almost strange to encounter a course without a virtual component. This new online learning offers new opportunities to people who had difficulties accessing higher education, be it for geographical or temporal reasons. The data provided by the National Education Council shows that the number of students registered in post-secondary higher education has risen considerably in Chile in the last decade, in parallel with the rise of courses which are offered by educational institutions (Consejo Nacional de Educación, 2018).

Nevertheless, it must be taken into account that not all users access the Internet with the same technical resources. The elderly and people with disabilities at times need assistive technologies to access and interact with the online content. The National Service for Disability defines assistive technologies as "Any device, software, equipment, system or instrument manufactured, developed or adapted, which is able to overcome and/or eliminate architectural, attitudinal or procedural barriers which people with disabilities face on a daily basis; thereby favoring their participation and social inclusion through an exercise in human rights" (Servicio Nacional de la discapacidad [SENADIS], 2018). According to The II National Study on Disability (SENADIS, 2016) in Chile there are three million people with some kind of disability. The cited study claims that $26.2 \%$ of the adult population uses assistive technologies aimed at improving their computer usage.

In the Chilean legal framework, Law 20422 (2010) establishes the regulation regarding equality of opportunities 
and social inclusion of people with disabilities. It defines universal access as the condition which must be met by environments, processes, goods, products and services, as well as objects and instruments, tools and devices, in order to be understandable and usable by all people, in a safe and comfortable way, in the most autonomous and natural manner possible.

In the international context, the Convention on the Rights of Persons with Disabilities states in article 24.5 that "Parties shall ensure that persons with disabilities are able to access general tertiary education, vocational training, adult education and lifelong learning without discrimination and on an equal basis with others" (UN, 2018).

The accessibility requirements that an online platform must meet are determined by the World Wide Web Consortium. The W3C defines web accessibility as "universal access to the Internet, regardless of the kind of hardware, software, network infrastructure, native language, culture, geographical location, or physical or mental ability". With the aim of protecting the rights of all people, W3C created the Web Accessibility Initiative (WAI). It is a team in charge of establishing guidelines of accessibility to online content known as Web Content Accessibility Guidelines (WCAG). Their goal is to guide web design towards one which is more universal, reducing the existing barriers and trying to make the contents accessible to the highest number of people possible (W3C, 2016).

\subsection{Principles and Directives of the WCAG 2.0}

The $\mathrm{W} 3 \mathrm{C}$ provides a series of recommendations organized into four fundamental principles to be used when developing a website (W3C, 2018a).

The principles are as follows:

1) Perceivable: "Information and user interface components must be presentable to users in ways they can perceive".

2) Operable: "User interface components and navigation must be operable".

3) Understandable: "Information and the operation of user interface must be understandable".

4) Robust: "Content must be robust enough that it can be interpreted reliably by a wide variety of user agents, including assistive technologies".

Each principle is comprised by a different number of guidelines which contain a series of checkpoints or success criteria to which a priority is assigned. Developers must comply by these in order to create a website which is more accessible for any type of user.

The priorities are as follows:

- Priority 1: This is the minimal accessibility requisite. If it is not met, it will impede access to a great number of users.

- $\quad$ Priority 2: It ought to be met. On the contrary, certain groups of users will encounter difficulties of access.

- Priority 3: This is the most advanced level where web accessibility is concerned. If it is not met, some users may experience difficulties of access.

In this way, it is possible to assign a level of adequacy or conformance to a website, according to the degree to which it has met the regulation (W3C, 2008).

There exist three conformance levels:

- Level A: Priority 1 checkpoints are successfully satisfied.

- Level AA: Priority 1 and 2 checkpoints are successfully satisfied.

- Level AAA: Priority 1, 2 and 3 checkpoints are successfully satisfied.

\subsection{Related Literature}

As shown in Table 1, numerous studies of web accessibility of educational platforms, e-learning platforms or portals, both at national and international level have been carried out. 
Table 1. Previous studies of web accessibility of university websites, ordered by year of publication

\begin{tabular}{|c|c|}
\hline Study & Reference \\
\hline $\begin{array}{l}\text { La accesibilidad de las webs de las universidades españolas. Balance } \\
2001-2006\end{array}$ & Ribera, Térmens, \& Frías (2009) \\
\hline $\begin{array}{l}\text { Dificultades en la accesibilidad web de las universidades españolas de acuerdo } \\
\text { a la norma wcag } 2.0\end{array}$ & $\begin{array}{l}\text { Chacón-Medina, Chacón-López, López-Justicia, \& } \\
\text { Fernández-Jiménez (2013) }\end{array}$ \\
\hline $\begin{array}{l}\text { Evaluación de la accesibilidad de páginas web de universidades españolas y } \\
\text { extranjeras incluidas en rankings universitarios internacionales }\end{array}$ & Hilera, Fernández, Suárez, \& Vilar (2013) \\
\hline Accesibilidad web en las Universidades del Ecuador. Análisis preliminar. & Navarrete \& Luján-Mora (2014) \\
\hline Accesibilidad web en el espacio universitario público argentino & Laitano (2015) \\
\hline Evaluating Web Accessibility of Educational Websites & Shawar (2015) \\
\hline $\begin{array}{l}\text { Evaluating accessibility of Malaysian public universities websites using a } \\
\text { checker and wave }\end{array}$ & Ahmi \& Mohamad (2016) \\
\hline $\begin{array}{l}\text { Accessibility evaluation of top university websites: a comparative study of } \\
\text { Kyrgyzstan, Azerbaijan, Kazakhstan and Turkey. }\end{array}$ & Ismailova \& Inal (2017) \\
\hline $\begin{array}{l}\text { Accessibility evaluation of top-ranking university websites in world, Oceania, } \\
\text { and Arab categories for home, admission, and course description webpages. }\end{array}$ & Alahmadi \& Drew (2017) \\
\hline La accesibilidad de los portales web de las universidades públicas andaluzas. & Balsells, González, Balsells, \& Chamorro (2017) \\
\hline
\end{tabular}

In all the above-mentioned studies, the authors made use of automatic tools in order to conduct an evaluation of web accessibility of the universities they assessed.

The work authored by Vargas et al. (2012) is the study which displays the biggest number of similarities with our own work. In the said study, the accessibility of Chilean university websites was analyzed, and the results revealed that none of the university homepages reached the minimum degree of accessibility, as proposed by W3C. The research carried out by Chacón-Medina et al. (2013) showed a great number of errors in web accessibility of online learning platforms offered by Spanish universities. In that same year, Hilera et al. (2013) compared Spanish universities with foreign universities in a study and discovered that the former had lower levels of accessibility. The results of a study carried out by Laitano (2015) in Argentinian public institutions were not very encouraging either: none of the assessed website displayed even the most elemental level of conformance with the WCAG.

A literature review revealed that the number of pages analyzed in every university website varies. In the study carried out by Ribera et al. (2009), two pages of each university website were analyzed. Alahmadi \& Drew (2017) decided to base their analysis on three pages. Other authors opted for analyzing only the homepage, provided that it is the most significant and most representative of the institutions they assessed (Espadinha, Pereira, Silva, \& Lopes, 2011; Ismail \& Kuppusamy, 2018; Laitano, 2015; Lazar \& Greenidge, 2006; Thompson, Burgstahler, \& Moore, 2010).

Regarding the choice of automatic evaluation tools, Web Accessibility Test (TAW) was used in numerous studies on web accessibility (Balsells et al., 2017; Caballero-Cortés, Faba-Pérez, \& Moya-Anegón, 2009; Chacón-Medina et al., 2013; Hilera et al., 2013; Karhu, Hilera, Fernández, \& Ríos, 2012) as well as WAVE (Ahmi \& Mohamad, 2016; Ismail \& Kuppusamy, 2018; Shawar, 2015).

\section{Method}

The $\mathrm{W} 3 \mathrm{C}$ has published a methodological guide which describes the procedures and the considerations to be taken into account by assessors in order to determine the degree of conformance with the WCAG 2.0 directive which a given website demonstrates. It is called Website Accessibility Conformance Evaluation Methodology (WCAG-EM). This exhaustive methodology constitutes a trustworthy method to evaluate a website and to determine its level of accessibility (W3C, 2018b).

\subsection{WCAG-EM}

WCAG-EM offers guidelines and considerations specified in the following five steps:

1) Define the scope of the evaluation: set the objective of the evaluation and the conformance level (A, AA, AAA) used in the evaluation. Indicate the software used (a web browser, assistive technology, etc.).

2) Explore the website: get to know and understand the website which is the subject of study, the type of website, its design, its functions, etc.

3) Choose a representative sample: make a selection of one or several websites to evaluate, since at times it is 
can be difficult to evaluate every and each one of the websites.

4) Evaluate the sample: determine where the website succeeds in meeting or fails to meet the WCAG 2.0 regulation, and the general level of accessibility. Save the evaluation results.

5) Report the results: gather all the data, asses it and calculate the points obtained.

\subsection{Web Accessibility Evaluation Tools}

In order to carry out this kind of analysis, it is possible to use software tools which help to evaluate the accessibility level of a given website (Serrano, Ocaña, \& Martos, 2009). The tools analyze the source code and point to the exact place where the error is found. Moreover, they detect barriers and difficulties of users who access a website. Nevertheless, they cannot determine whether a website is or is not accessible, as human verification is needed to achieve this end.

To begin the present analysis, source code validators set by the W3C were used to check the HTML/XTML syntax, as well as the correct use of CSS style sheets.

Subsequently, WAVE was used in the second step of the process. WAVE is an online application aimed at evaluating to what degree the WCAG 2.0 guidelines are met by websites. Although the application offers different options, it was used primarily to check if the textual elements of the website have the correct color contrast proportion.

The last tool used in the analysis was TAW, an application developed by the Foundation Technological Center of Information and Communication (CTIC) and used in numerous web accessibility studies. This tool carries out an analysis of a webpage according to Web Content Accessibility Guidelines and provides a detailed report which includes errors and warnings found on every page, organizing all of this data into four fundamental web accessibility principles: Perceivable, Operable, Understandable and Robust.

\subsection{Sampling Procedures}

The sample used in the present study consisted of all the learning platforms of Chilean universities found on the list of The World University Rankings (Table 2). The ranking measures the quality of teaching, research, knowledge transfer and international presence of these entities.

Table 2. Chilean universities listed in The World University Rankings

\begin{tabular}{|c|c|}
\hline Institution & Website \\
\hline Pontifical Catholic University of Chile & http://www.uc.cl/ \\
\hline Federico Santa María Technical University & http://www.usm.cl/ \\
\hline Diego Portales University & https://www.udp.cl/ \\
\hline University of Chile & http://www.uchile.cl/ \\
\hline University of Concepción & http://www.udec.cl/pexterno/ \\
\hline University of Santiago, Chile & https://www.usach.cl/ \\
\hline Andrés Bello University & http://www.unab.cl/ \\
\hline Austral University of Chile & https://www.uach.cl/ \\
\hline Pontifical Catholic University of Valparaíso & http://www.pucv.cl/ \\
\hline University of Valparaíso & http://www.uv.cl/ \\
\hline University of La Frontera & http://www.ufro.cl/ \\
\hline University of Talca & http://www.utalca.cl/link.cgi/ \\
\hline Catholic University of the North & http://www.ucn.cl/ \\
\hline
\end{tabular}

\section{Results}

To begin with, we conducted an analysis using the validators recommended by the $\mathrm{W} 3 \mathrm{C}$ in order to check the HTML code and the CSS style sheets. A source code which is free of errors enables the interaction with assistive technologies, thus improving the user experience of visiting a website. The results can be seen in Table 3 . 
Table 3. Syntax errors in the HTML code and CSS of the homepages of selected universities

\begin{tabular}{lcccc}
\hline \multirow{2}{*}{ Institution } & \multicolumn{2}{c}{ HTML code validator } & \multicolumn{2}{c}{ CSS style sheets validator } \\
\cline { 2 - 5 } & Errors & Warnings & Errors & Warnings \\
\hline University of Chile & 25 & 22 & 16 & 272 \\
Pontifical Catholic University of Chile & 86 & 32 & 10 & 47 \\
University of Concepción & 2 & 9 & 1066 & 398 \\
Federico Santa María University & 16 & 1 & 21 & 615 \\
University of Santiago, Chile & 24 & 21 & 10 & 121 \\
Andrés Bello University & 166 & 64 & 4 & 276 \\
Austral University of Chile & 86 & 55 & 4 & 16 \\
Pontifical Catholic Uversity of Valparaíso & 42 & 8 & 15 & 161 \\
University of Valparaíso & 40 & 17 & 4 & 32 \\
Diego Portales University & 47 & 19 & 14 & 66 \\
University of La Frontera & 2 & 30 & 104 & 979 \\
University of Talca & 174 & 44 & 242 & 16 \\
Catholic University of the North & 13 & 27 & 358 \\
\hline
\end{tabular}

WAVE was used with the aim of assessing the color combinations in the foreground and in the background of the selected websites. The results are presented in Table 4.

Table 4. Contrast errors found on home pages by WAVE

\begin{tabular}{lc}
\hline Institution & Contrast Errors \\
\hline University of Chile & 39 \\
Pontifical Catholic University of Chile & 29 \\
University of Concepción & 25 \\
Federico Santa María Technical University & 38 \\
University of Santiago, Chile & 14 \\
Andrés Bello University & 3 \\
Austral University of Chile & 37 \\
Pontifical Catholic University of Valparaíso & 19 \\
University of Valparaíso & 9 \\
Diego Portales University & 9 \\
University of La Frontera & 17 \\
University of Talca & 8 \\
Catholic University of the North & 27 \\
\hline
\end{tabular}

Finally, an automatic evaluation was carried out using the TAW tool which showed the existence of barriers to access for the elderly and/or those with disabilities, as can be observed in Table 5. 
Table 5. Web accessibility errors on home pages of university websites categorized by principle

\begin{tabular}{lccccc}
\hline Institution & Perceivable & Operable & Understandable & Robust & Total \\
\hline University Chile & 12 & 11 & 1 & 4 & 28 \\
Pontifical Catholic University of Chile & 14 & 8 & 1 & 11 & 34 \\
University of Concepción & 11 & 0 & 5 & 6 & 22 \\
Federico Santa María University & 2 & 0 & 0 & 7 & 9 \\
University of Santiago, Chile & 3 & 6 & 0 & 6 & 15 \\
Andrés Bello University & 26 & 36 & 1 & 55 & 118 \\
Austral University of Chile & 4 & 24 & 3 & 2 & 33 \\
Pontifical Catholic University of Valparaíso & 28 & 0 & 2 & 5 & 35 \\
University of Valparaíso & 40 & 33 & 1 & 4 & 78 \\
Diego Portales University & 15 & 13 & 1 & 5 & 34 \\
University of La Frontera & 1 & 1 & 1 & 1 & 4 \\
University of Talca & 42 & 25 & 4 & 48 & 119 \\
Catholic University of the North & 53 & 2 & 19 & 24 & 98 \\
Total & 251 & 159 & 39 & 178 & 627 \\
\hline
\end{tabular}

The automatic evaluation tool, TAW, indicated that all the online learning platforms display errors in web accessibility. Having categorized the accessibility errors by principle (Figure 1), it can be seen that the percentage of the Perceivable principle (40\%) constitutes almost half of the errors, thus greatly impeding the regulation from being met.

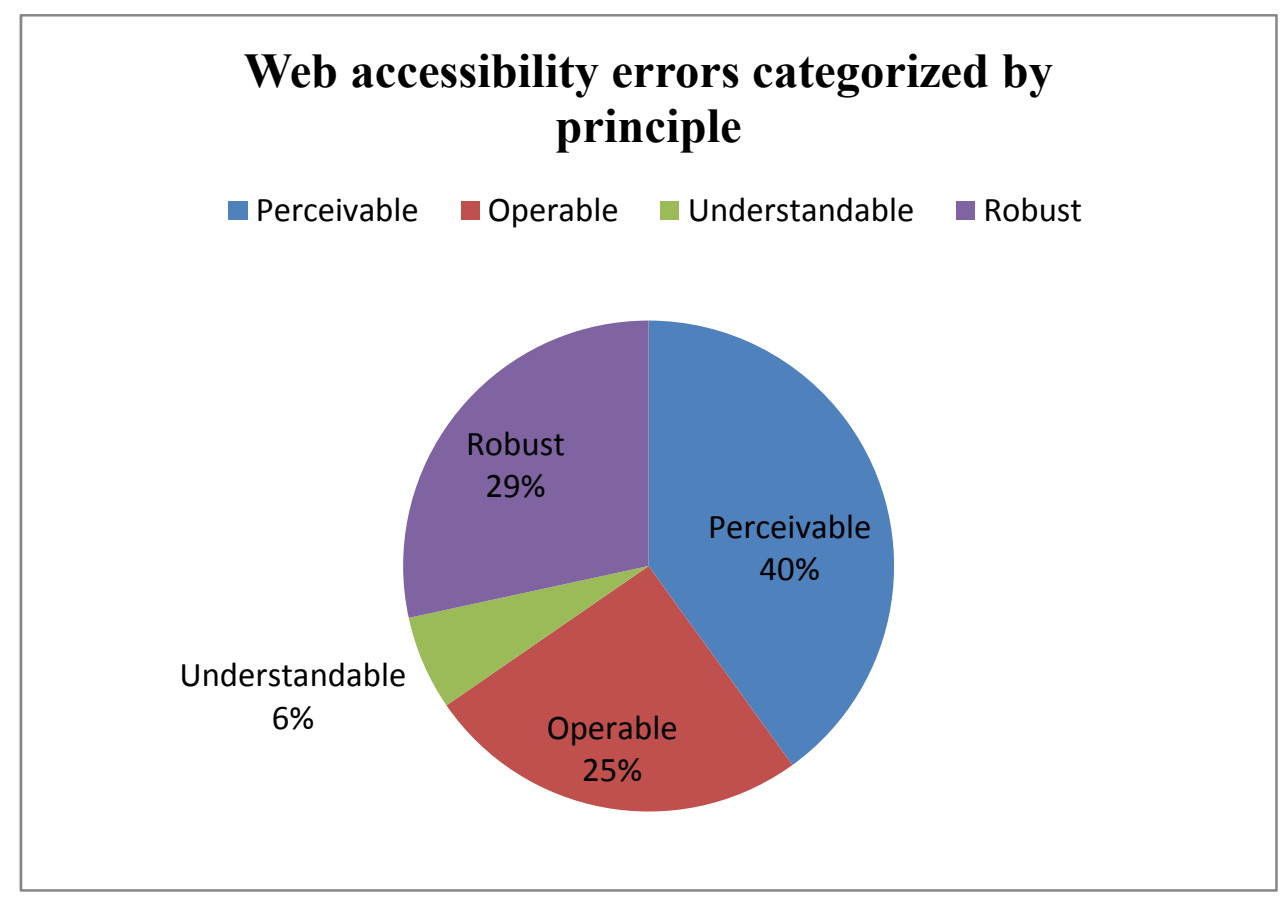

Figure 1. Total errors categorized by principle

Having analyzed the results by principle and guideline, the following results were obtained:

TAW detects the omission of textual alternatives to non-textual contents (mainly images), which is a fundamental need for a person who interacts with the websites using a screen reader. In addition, the tools spots errors in the adaptation of the content according to the necessities of each user, which is especially important for people with disabilities who make use of assistive technologies. The biggest number of errors was found in the Operable principle ( $25 \%$ of the total) in relation to the omission of text in the hyperlinks. The link description helps the users know where they are and where they are going to navigate. The most common error found in the Understandable principle ( $6 \%$ of the total) was the correct use of the label element in the forms. Moreover, TAW found $29 \%$ of total 
errors in the Robust principle, the aim of which is to facilitate the interaction of web content and assistive technologies.

As the last step, a comparative study between the present one and the one conducted by Vargas et al. (2012) was carried out to see the evolution of accessibility that the websites displayed. The average of errors categorized by principle was used in both studies, as can be seen in Table 6 .

Table 6. Average of errors categorized by principle

\begin{tabular}{ccccc}
\hline Year & Perceivable & Operable & Understandable & Robust \\
\hline 2012 & $62.20 \%$ & $11.35 \%$ & $6.43 \%$ & $20.02 \%$ \\
2018 & $40 \%$ & $25 \%$ & $6 \%$ & $29 \%$ \\
\hline
\end{tabular}

The results of the comparison reveal that the Perceivable principle continues to be the one which displays the biggest number of errors in both studies (Figure 2).

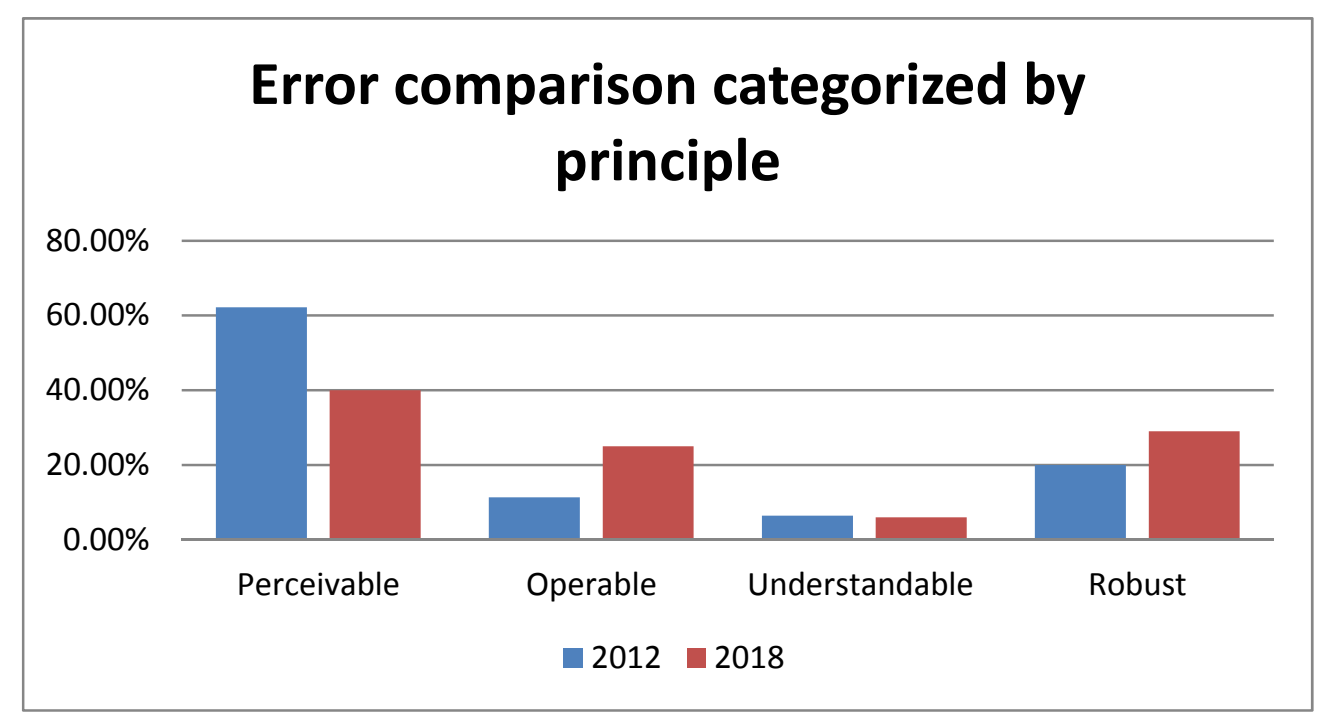

Figure 2. Error comparison categorized by principle

The present study shows a decrease in the average number of errors in the Perceivable principle, together with an increase in the Operable principle.

\subsection{Recommendations}

As the research proves, web accessibility evaluation tools can help designers and developers to identify potential accessibility issues. Web designers can use WAVE or similar tools to check if the designs implemented in the universities offer adequate color contrast. Web developers can also use tools such as validators developed and designed by the $\mathrm{W} 3 \mathrm{C}$ in order to help them assess their code, which would improve the experience of the users who use assistive technologies when visiting a website. Development teams can carry out periodic checks by using tools such as TAW that perform an analysis according to the fundamental principles on which WCAG 2.0 is based. All these tools provide very detailed reports which, combined with human judgment, form an excellent combination to be used at different stages of web design and the development process.

\section{Conclusion}

The aim of this work has been to analyze the degree to which the websites of Chilean universities listed in The World University Rankings, meet the WCAG 2.0 regulation. Various automatic tools such as HTML and CSS validators, WAVE and TAW were used to this end.

As indicated by the $\mathrm{W} 3 \mathrm{C}$ and as proven by the present analysis, the use of such automatic tools is extremely helpful when trying to detect and solve possible errors caused by the failure to meet the regulation.

The results of the present studies bear resemblance to previous published studies on web accessibility of 
universities. As expected, none of the universities have completely achieved conformance level AA, as established by the WCAG 2.0 directive. The biggest problems displayed by the websites are found in how the information is perceived by the users and difficulties in web usage itself. These difficulties are even greater in the case of a person with disabilities using assistive technologies.

After conducting a comparative study with the research carried out by Vargas et al. (2012) on the accessibility of Chilean university online portals, it has been observed that there remain difficulties of access to information on the websites of Chilean universities.

The WCAG 2.0 is designed to protect the people's right to access information and this study proves the existence of barriers for the elderly and/or people with disabilities trying to access the websites of Chilean universities.

The development of online platforms should be built on a solid foundation of the concept of Universal Design, facilitating the social inclusion of people with disabilities, as well as access to information to the wider public. The virtual university is an opportunity to improve the education of all and to reduce inequality among individuals. Its aim is to favor the social inclusion of people with disabilities and facilitate the access to information, promoting and achieving a true educational inclusion.

\section{References}

Ahmi, A., \& Mohamad, R. (2016). Evaluating accessibility of malaysian public universities websites using achecker and wave. Journal of ICT, 15(2), 193-214.

Alahmadi, T., \& Drew, S. (2017). An evaluation of the accessibility of top-ranking university websites: Accessibility rates from 2005 to 2015. Journal of Open Flexible and Distance Learning, 21(1), 7-24.

Balsells, L. A. C., González, J. C. G., Balsells, M. A. C., \& Chamorro, V. A. P. (2017). La accesibilidad de los portales web de las universidades públicas andaluzas. Revista española de Documentación Científica, 40(2), 169. https://doi.org/10.3989/redc.2017.2.1372

Caballero-Cortés, L., Faba-Pérez, C., \& Moya-Anegón, F. de. (2009). Evaluación comparativa de la accesibilidad de los espacios web de las bibliotecas universitarias españolas y norteamericanas. Investigación bibliotecológica, 23(47), 45-66. Retrieved from http://www.scielo.org.mx/scielo.php?script= sci_abstract\&pid=S0187-358X2009000100003\&lng=es\&nrm=iso\&tlng=en

Chacón-Medina, A., Chacón-López, H., López-Justicia, M. D., \& Fernández-Jiménez, C. (2013). Dificultades en la Accesibilidad Web de las Universidades Españolas de acuerdo a la Norma WCAG 2.0. Revista española de Documentación Cientifica, 36(4), 025. https://doi.org/10.3989/redc.2013.4.1009

Consejo Nacional de Educación. (2018). Retrieved from https://www.cned.cl/

Espadinha, C., Pereira, L. M., Silva, F. M. da, \& Lopes, J. B. (2011). Accessibility of Portuguese Public $\begin{array}{llll}\text { Universities' } \quad \text { sites. Disability and } & \text { Rehabilitation, 33(6), }\end{array}$ https://doi.org/10.3109/09638288.2010.498554

Hilera, J. R., Fernández, L., Suárez, E., \& Vilar, E. T. (2013). Evaluación de la accesibilidad de páginas web de universidades españolas y extranjeras incluidas en rankings universitarios internacionales. Revista española de Documentación Científica, 36(1), 004. https://doi.org/10.3989/redc.2013.1.913

Ismail, A., \& Kuppusamy, K. S. (2018). Accessibility of Indian universities' homepages: An exploratory study. Journal of King Saud University-Computer and Information Sciences, 30(2), 268-278. https://doi.org/10.1016/j.jksuci.2016.06.006

Ismailova, R., \& Inal, Y. (2017). Accessibility evaluation of top university websites: a comparative study of Kyrgyzstan, Azerbaijan, Kazakhstan and Turkey. Universal Access in the Information Society, 1-9. https://doi.org/10.1007/s10209-017-0541-0

Karhu, M., Hilera, J. R., Fernández, L., \& Ríos, R. (2012). Accessibility and readability of university websites in Finland. https://doi.org/info:doi/10.17411/jacces.v2i2.70

Laitano, M. I. (2015). Accesibilidad web en el espacio universitario público argentino. Revista española de Documentación Científica, 38(1), e079. https://doi.org/10.3989/redc.2015.1.1136

Lazar, J., \& Greenidge, K.-D. (2006). One year older, but not necessarily wiser: an evaluation of homepage accessibility problems over time. Universal Access in the Information Society, 4(4), 285-291. https://doi.org/10.1007/s10209-003-0087-1

Ministerio de Planificación. (2010, febrero 10). LEY-20422 10-FEB-2010. Retrieved from 
https://www.leychile.cl/Navegar?idLey=20422

Navarrete, R., \& Luján, S. (2014). Accesiblidad web en las Universidades del Ecuador. Análisis preliminar. Revista Politécnica, $\quad 33(1) . \quad$ Retrieved from https://www.revistapolitecnica.epn.edu.ec/ojs2/index.php/revista_politecnica2/article/view/94

Ribera, M., Térmens, M., \& Frías, A. (2009). La accessibilidad de las webs de las universidades españolas. Balance 2001-2006. Revista española de Documentación Científica, 32(3), 66-88. https://doi.org/10.3989/redc.2009.3.683

SENADIS. (2016). II ESTUDIO NACIONAL DE LA DISCAPACIDAD EN CHILE. Retrieved from http://observatorio.ministeriodesarrollosocial.gob.cl/endisc/docs/Libro_Resultados_II_Estudio_Nacional_de _la_Discapacidad.pdf

SENADIS. (2018). Servicio Nacional de la Discapacidad. Retrieved from https://www.senadis.gob.cl/documentos/listado/146/accesibilidad

Serrano, E. S., Ocaña, A. M., \& Martos, I. O. (2009). DIRECTRICES TÉCNICAS REFERIDAS A LA ACCESIBILIDAD WEB. Anales de Documentación, 12(0), 255-280. Retrieved from http://revistas.um.es/analesdoc/article/view/70361

Shawar, B. A. (2015). Evaluating Web Accessibility of Educational Websites. International Journal of Emerging Technologies in Learning (IJET), 10(4), 4-10. https://doi.org/10.3991/ijet.v10i4.4518

Thompson, T., Burgstahler, S., \& Moore, E. J. (2010). Web accessibility: a longitudinal study of college and university home pages in the northwestern United States. Disability and Rehabilitation. Assistive Technology, 5(2), 108-114. https://doi.org/10.3109/17483100903387424

UN. (2018). Educación-Desarrollo Sostenible. Retrieved from https://www.un.org/sustainabledevelopment/es/ education/

Vargas, Cl., Sepúlveda, A., Muñoz, R., \& Providel, E. (2012). Publication-Accesibilidad en Portales Universitarios Chilenos. Proceedings XXIV Encuentro Chileno de Computación ECC-2012. Retrieved from http://informatica.uv.cl/index.php/es/investigacion/publicaciones/publicaciones?view=publication\&task=sh ow\&id=94

W3C. (2008). Web Content Accessibility Guidelines (WCAG) 2.0. Retrieved from https://www.w3.org/TR/WCAG20/

W3C. (2016). Understanding WCAG 2.0. $\quad$ Retrieved from https://www.w3.org/TR/UNDERSTANDING-WCAG20/Overview.html\#contents

W3C. (2018a). Accessibility Principles. $\quad$ Retrieved https://www.w3.org/WAI/fundamentals/accessibility-principles/

W3C. (2018b). WCAG-EM Overview: Website Accessibility Conformance Evaluation Methodology. Retrieved from https://www.w3.org/WAI/test-evaluate/conformance/wcag-em/

\section{Copyrights}

Copyright for this article is retained by the author(s), with first publication rights granted to the journal.

This is an open-access article distributed under the terms and conditions of the Creative Commons Attribution license (http://creativecommons.org/licenses/by/4.0/). 